\title{
MECHANICAL PROPERTIES AND MICROSTRUCTURES OF BIO-INERT LAYERS OF CHROME OXIDE COATINGS DEPOSITED BY THE APS PROCESS
}

\author{
Mihailo R. Mrdak \\ Research and Development Center IMTEL Communications a.d., \\ Belgrade, Republic of Serbia, \\ e-mail: drmrdakmihailo@gmail.com, \\ ORCID iD: (Dhttp://orcid.org/0000-0003-3983-1605
}

http://dx.doi.org/10.5937/vojtehg66-14009

\author{
FIELD: Chemical Technology \\ ARTICLE TYPE: Original Scientific Paper \\ ARTICLE LANGUAGE: English
}

\section{Summary:}

Plasma spray $\mathrm{Cr}_{2} \mathrm{O}_{3}$ ceramic layers are used as a separate coating or as a supplement to bio-reactive organic composite ceramics $\mathrm{Ca}_{10}\left(\mathrm{PO}_{4}\right)_{6}(\mathrm{OH})_{2}-\mathrm{Al}_{2} \mathrm{O}_{3}-\mathrm{ZrO}_{2}-\mathrm{Cr}_{2} \mathrm{O}_{3}$ and other bio-inert ceramics in composites of the types $\mathrm{Al}_{2} \mathrm{O}_{3}-\mathrm{ZrO}_{2}-\mathrm{SrO}-\mathrm{Cr}_{2} \mathrm{O}_{3}-\mathrm{Y}_{2} \mathrm{O}_{3}, \mathrm{ZrO}_{2}-\mathrm{TiO}_{2}-\mathrm{Cr}_{2} \mathrm{O}_{3}$ and $\mathrm{TiO}_{2}-\mathrm{Cr}_{2} \mathrm{O}_{3}$ to increase the mechanical properties and resistance components of artificial joints on sliding abrasion and corrosion. This paper analyzes the influence of the plasma gun distance from the substrate on the mechanical properties and the microstructure of $\mathrm{Cr}_{2} \mathrm{O}_{3}$ layers deposited with the current of $40 \mathrm{~kW}$. The aim was to deposit layers with optimal characteristics that will enable the effective implementation of $\mathrm{Cr}_{2} \mathrm{O}_{3}$ layers on substrates of steel implants exposed to dry friction without lubrication and to corrosion of living tissues. The mechanical properties were tested by examining microhardness layers using the $H V_{0.3}$ method and the strength was tested by tensile testing. The surface of powder particles was examined by SEM. The microstructures of layers were analyzed with the use of an optical microscope (OM) and a scanning electron microscope (SEM). The test results confirmed a possibility of effective application of bio-inert layers of $\mathrm{Cr}_{2} \mathrm{O}_{3}$ with other ceramics intended for the production of functional implants.

Keywords: substrates, microstructures, corrosion,ceramics.

ACKNOWLEDGEMENT: The author is thankful for the financial support from the Ministry of Education and Science of the Republic of Serbia (national projects OI 174004). 


\section{Introduction}

The APS - atmospheric plasma spray process is one of the technologies used for the deposition of bio-reactive and bio-inert coatings on the surface of implants (Bag \& Biswas, 2016, pp.117-128). For the majority of plasma spray coatings, argon (Ar) can be used as a carrier gas. However, for the melting of metal oxide powders in high temperature plasma, oxygen is often used as a carrier gas in order to minimize the decomposition of oxide powder (Morks \& Akimoto, 2008, p.1). The degree of powder melting depends on the size and the particle size distribution, the spray system used for powder deposition and the coating deposition parameters (Wang \& Shaw, 2007, pp.34), (Trifa et al, 2005, pp.54-69). In the previously published papers, it was found that the coating microstructure depends on the spraying conditions (Mrdak, 2017a, pp.3044), (Mrdak, 2017b, pp.378-391). Layers of plasma sprayed oxides are widely used for improving resistance to wear, abrasion and corrosion. This includes a wide range of deposited materials of metal oxides. One such material is $\mathrm{Cr}_{2} \mathrm{O}_{3}$ oxide, which is characterized by high resistance to sliding wear and corrosion. $\mathrm{Cr}_{2} \mathrm{O}_{3}$ oxide produces chemically most inert thermal spray layers resistant to abrasion of all oxides produced in the Sulzer Metco company. Coatings are very dense and have a low coefficient of friction without the addition of lubricants. Because of that, they have found application in the process of implants production (Material Product Data Sheet, 2012). An important feature of $\mathrm{Cr}_{2} \mathrm{O}_{3}$ oxide is non-toxicity and biocompatibility. Due to strong bonds of valence electrons of chromium and oxygen atoms, $\mathrm{Cr}_{2} \mathrm{O}_{3}$ oxide is stable and bio-inert. The ceramic coating or $\mathrm{Cr}_{2} \mathrm{O}_{3}$ oxide film deposited on the surface of the implant passivates the alloy substrate surface (Co-Cr, Co-Cr-Mo, Ti-6Al-4V i Ti$6 \mathrm{Al}-7 \mathrm{Nb}$ ) and prevents the migration of toxic metal ions from the substrate into the surrounding tissue (Ogwu et al, 2016). $\mathrm{Cr}_{2} \mathrm{O}_{3}$ oxide has a high resistance to corrosion in contact with living tissues and goood tribological behavior during friction and abrasive wear (Pang et al, 2007, pp.35313537), (Szafarska \& Iwaszko, 2012, pp.215-221). Depending on the applied thermal spray coating process, coatings have a variety of microstructures and properties. The homogeneity of the coating structure significantly affects its tribological behavior. However, plasma spray of the $\mathrm{Cr}_{2} \mathrm{O}_{3}$ oxide coating has the highest abrasion resistance in dry conditions and in lubrication conditions compared with $\mathrm{Al}_{2} \mathrm{O}_{3}$ and $\mathrm{TiO}_{2}$ coatings (Cetinel et al, 2008, pp.259-265). During the process of powder melting in plasma, one part of $\mathrm{Cr}_{2} \mathrm{O}_{3}$ oxide is decomposed due to plasma high temperature. After the dual diagram $\mathrm{Cr}-\mathrm{O}, \mathrm{Cr}_{2} \mathrm{O}_{3}$ oxide occurs in several 
crystalline phases such as $\mathrm{Cr}_{3} \mathrm{O}_{4}(29,1 w t . \% \mathrm{O}), \quad \mathrm{Cr}_{2} \mathrm{O}_{3} \quad$ (32wt.\%O), $\mathrm{CrO}_{2}(38,1 w t . \% \mathrm{O}), \quad \mathrm{Cr}_{5} \mathrm{O}_{12}(42,5 \mathrm{wt} . \% \mathrm{O}), \quad \mathrm{Cr}_{6} \mathrm{O}_{15}(43,4 \mathrm{wt} . \% \mathrm{O}) \quad$ and $\mathrm{CrO}_{3}(48 w t . \% O)$ (ASM Handbook, 1992). Black $\alpha-\mathrm{Cr}_{2} \mathrm{O}_{3}$ oxide with a hexagonal lattice is used for deposition; the lattice basal planes are conveniently distributed in the coating thus giving good sliding properties. With the typical spraying parameters, $\mathrm{Cr}_{2} \mathrm{O}_{3}$ coating is somewhat understoichiometric, and its microstructure consists of the initial oxide type $\alpha-\mathrm{Cr}_{2} \mathrm{O}_{3}$, dark gray in color, and light gray $\mathrm{Cr}_{3} \mathrm{O}_{4}, \mathrm{CrO}$ and $\mathrm{CrO}_{2}$ oxides (Khanna \& Bhat, 2006).

This paper presents the results of the influence of the plasma gun distance from the substrate on the mechanical properties and the microstructure of $\mathrm{Cr}_{2} \mathrm{O}_{3}$ layers. Powder is deposited on the metal surface at a distance of $90 \mathrm{~mm}, 100 \mathrm{~mm}$ and $110 \mathrm{~mm}$. The adhesion strength, microhardness and microstructural characteristics of $\mathrm{Cr}_{2} \mathrm{O}_{3}$ coating were analysed; these coatings have layers of the best features which enable efficient implementation on the substrates in the conditions of bet lubrication friction and corrosion present on implants.

\section{Materials and experimental details}

For depositing layers of $\mathrm{Cr}_{2} \mathrm{O}_{3}$, Sulzer Metco $106 \mathrm{NS}$ powder was used; the powder particle surface is shown in SEM photomicrographs in Figure 1.

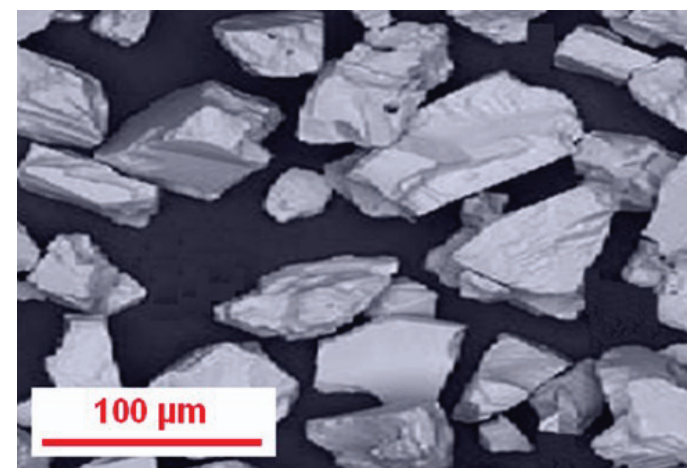

Figure 1 - (SEM) micrography of $\mathrm{Cr}_{2} \mathrm{O}_{3}$ powder particles

Puc. 1 - (SEM) микрография частиц порошка $\mathrm{Cr}_{2} \mathrm{O}_{3}$

Слика 1 - (SEM) микрографрија честица праха $\mathrm{Cr}_{2} \mathrm{O}_{3}$

The applied powder was the $\alpha-\mathrm{Cr}_{2} \mathrm{O}_{3}$ modification produced by sintering and grinding to a granulation of $11 \mu \mathrm{m}-90 \mu \mathrm{m}$ (Material Product Data Sheet, 2012). $\mathrm{Cr}_{2} \mathrm{O}_{3}$ coating layers are deposited on substrates of Č.4171 (X15Cr13 EN10027) steel in the thermally untreated condition. To 
assess the microhardness and microstructure of coatings, the substrates had dimensions of $70 \times 20 \times 1.5 \mathrm{~mm}$. To assess the adhesion / cohesion strength of the layers, the substrate samples had dimensions $\varnothing 25 \times 50 \mathrm{~mm}$. The mechanical properties of layers were assessed in accordance with standard ASTM C633-1, 2008. The paper presents the minimum and maximum microhardness values $\mathrm{HV}_{0.3}$ as well as the mean values of tensile bond strength.

The analysis of the microstructure of $\mathrm{Cr}_{2} \mathrm{O}_{3}$ layers was performed by an optical microscope. The assessment of content, distribution and size of micro pores was performed on five photos - OM at 200x magnification. The paper presents the mean value of the content of pores.

$\mathrm{Cr}_{2} \mathrm{O}_{3}$ powder was deposited at atmospheric pressure with a plasma spray of the Plasmadyne system. The SG-100 plasma gun which was used for powder deposition consisted of a cathode type K 1083A-129, an anode type A 2083-145 and a gas injector type GI 1083A-113. The plasma gas was a mixture of gases $\mathrm{Ar} / \mathrm{He}$ and the power supply was up to $40 \mathrm{~kW}$. The powder deposition parameters are shown in Table 1. The deposited coatings had a thickness of $0.18 \mathrm{~mm}-0.20 \mathrm{~mm}$.

Table 1 - Plasma spray parameters

Таблица 1 - Параметры плазменного напыления

Табела 1 - Плазма спреј параметри

\begin{tabular}{|l|c|c|c|}
\hline Deposition parameters & \multicolumn{3}{|c|}{ Values } \\
\hline Plasma current, I (A) & 800 & 800 & 800 \\
\hline Plasma Voltage, U (V) & 40 & 40 & 40 \\
\hline $\begin{array}{l}\text { Primary plasma gas } \\
\text { flow rate, Ar (I/min) }\end{array}$ & 47 & 47 & 47 \\
\hline $\begin{array}{l}\text { Secondary plasma gas } \\
\text { flow rate, He (I/min) }\end{array}$ & 12 & 12 & 12 \\
\hline $\begin{array}{l}\text { Carrier gas } \\
\text { flow rate, Ar (I/min) }\end{array}$ & 6 & 6 & 6 \\
\hline Powder feed rate, (g/min) & 40 & 40 & 40 \\
\hline Stand-off distance, (mm) & 90 & 100 & 110 \\
\hline
\end{tabular}

\section{Results and Discussion}

Distances of the plasma gun from the substrate had an important influence on the mechanical properties and microstructure of the deposited layers. The measured values of micro hardness and tensile strength of 
$\mathrm{Cr}_{2} \mathrm{O}_{3}$ coatings depending on the distance of the plasma gun from the substrates are shown in Figures 2 and 3 . The layers deposited with a minimum spray distance of $90 \mathrm{~mm}$ have the largest range of microhardness of $230 \mathrm{HV}_{0.3}$ and the lowest value of $1030 \mathrm{HV}_{0.3}$ to $1260 \mathrm{HV}_{0.3}$. The highest values of microhardness $1270 \mathrm{HV}_{0.3}$ to $1395 \mathrm{HV}_{0.3}$ occur in the layers deposited with the largest spray distance of $110 \mathrm{~mm}$. The smallest microhardness range of $180 \mathrm{HV} 0.3$ was measured in these layers.

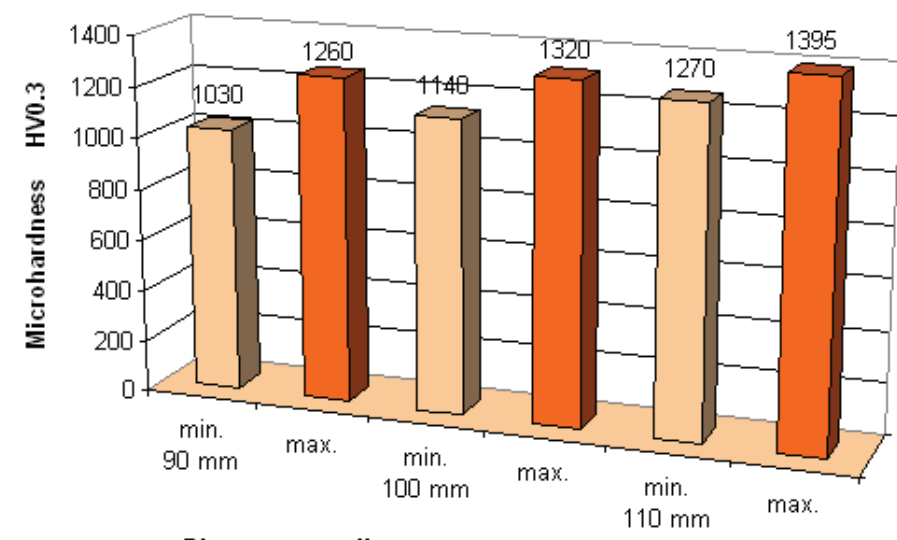

Plasma spray distance $\mathbf{m m}$

Figure 2 - Microhardness of $\mathrm{Cr}_{2} \mathrm{O}_{3}$ layers

Puc. 2 - Микротвердость покрытия $\mathrm{Cr}_{2} \mathrm{O}_{3}$

Слика 2 - Микротврдоћа $\mathrm{Cr}_{2} \mathrm{O}_{3}$ слојева

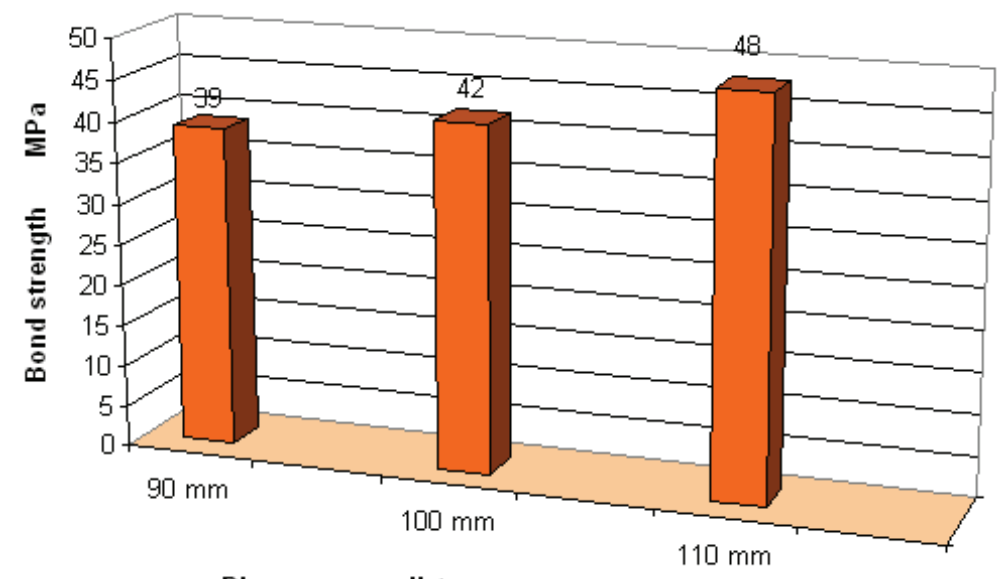

Plasma spray distance $\mathrm{mm}$

Figure 3 - Bond strength of $\mathrm{Cr}_{2} \mathrm{O}_{3}$ layers

Puc. 3 - Прочность связи слоев покрытия $\mathrm{Cr}_{2} \mathrm{O}_{3}$

Слика 3 - Чврстоћа споја $\mathrm{Cr}_{2} \mathrm{O}_{3}$ слојева 
With the increase of the spray distance, powder particles melt better due to a longer stay in plasma. Better powder melting enabled the deposition of layers of higher density and higher adhesion / cohesion strength, which was confirmed by examining the deposited coatings.

The tensile strength of the bond of the $\mathrm{Cr}_{2} \mathrm{O}_{3}$ coating deposited with the smallest spray distance of $90 \mathrm{~mm}$ had the lowest value of the bond strength of $39 \mathrm{MPa}$. A smaller spray distance reduces the residence time of particles in plasma, therefore causing poorer melting of powder particles. The coating $\mathrm{Cr}_{2} \mathrm{O}_{3}$ deposited with the largest spray distance of $110 \mathrm{~mm}$ has the highest bond strength of $48 \mathrm{MPa}$. Due to a longer stay in plasma, powder particles have sufficient time to melt fully and bind tightly to the surface of the substrate and the particles from the previously deposited layers.

The metallographic analysis of $\mathrm{Cr}_{2} \mathrm{O}_{3}$ coatings showed a good bonding between the coating and the substrate; it also showed that there are no residual particles of corundum due to roughening at the interface. Micro and macro cracks are not observed along the interface; there is neither separation of the coating along the sample edges nor peeling off of the coatings from the substrates. There are neither micro/macro cracks nor unmelted powder particles in the deposited layers, which contributed to coatings having good adhesion / cohesion strength.

The microstructures of $\mathrm{Cr}_{2} \mathrm{O}_{3}$ coatings were in accordance with the mechanical characteristics of the coatings. The distance of the plasma gun from the substrate had a significant impact on the degree of melting and deformation of particles in collision with the substrate. Depending on the substrate distance, the layers of the deposited coatings had a different share, distribution and size of micro pores in the coating. Figure 4 shows the microstructure of $\mathrm{Cr}_{2} \mathrm{O}_{3}$ coatings deposited with a minimum distance of $90 \mathrm{~mm}$ from the substrate. The coating predictably had the highest proportion of micro pores, which resulted in the layers having minimum microhardness and adhesion strength. In the layers, there are coarse micro pores larger than $20 \mu \mathrm{m}$. The total share of micro pores was $9.3 \%$. Because of smaller distances of the substrate and a shorter stay of powder particles in plasma, particles are half melted and, therefore, less deformed in collision with the substrate. As a result, the bonding surface between the deposited particles is reduced, the content of pores is increased as well as the presence of coarse pores which all leads to inferior mechanical properties of the coating. 


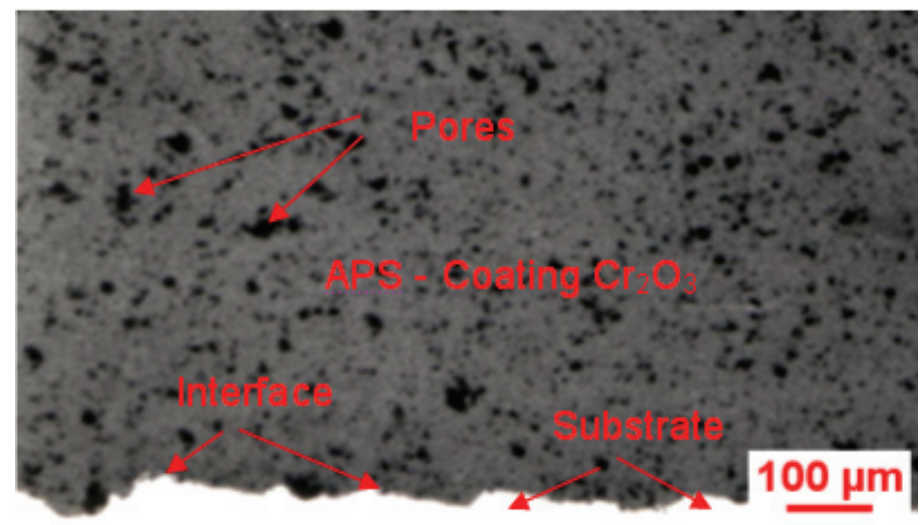

Figure $4-\mathrm{Cr}_{2} \mathrm{O}_{3}$ coating microstructure deposited from a distance of $90 \mathrm{~mm}$

Puc. 4 - Микроструктура покрытия $\mathrm{Cr}_{2} \mathrm{O}_{3}$, нанесенного с расстояния 90 мм Слика 4 - Микроструктура $\mathrm{Cr}_{2} \mathrm{O}_{3}$ превлаке са одстојањем $90 \mathrm{~mm}$

Figures 5 and 6 show the microstructure of the $\mathrm{Cr}_{2} \mathrm{O}_{3}$ coating deposited on the substrate from a distance of $110 \mathrm{~mm}$ which had the best microstructure and mechanical properties.

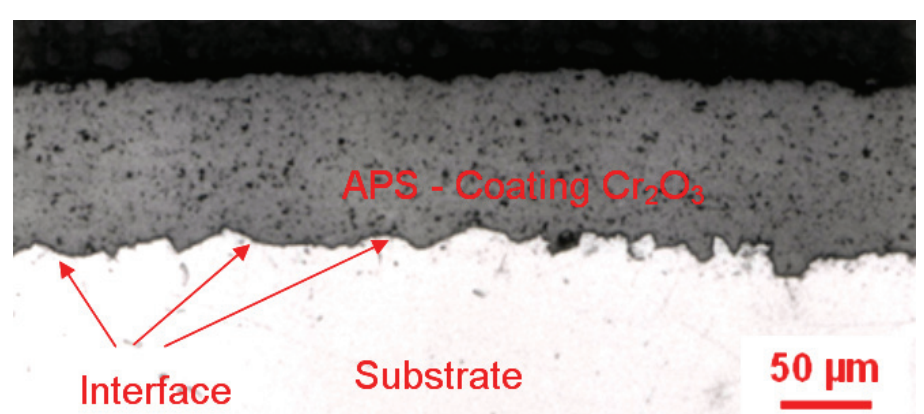

Figure $5-\mathrm{Cr}_{2} \mathrm{O}_{3}$ coating microstructure deposited from a distance of $110 \mathrm{~mm}$

Puc. 5 - Микроструктура покрытия $\mathrm{Cr}_{2} \mathrm{O}_{3}$, нанесенного с расстояния 110 мм Слика 5 - Микроструктура $\mathrm{Cr}_{2} \mathrm{O}_{3}$ превлаке са одстојањем $110 \mathrm{~mm}$

A large distance from the substrate enabled the best melting of $\mathrm{Cr}_{2} \mathrm{O}_{3}$ powder particles and a uniform deposition of molten droplets on the surface of the substrate and previously deposited layers. In a collision with the substrate, droplets of molten particles spilled in a regular pattern and formed thin lamelae with a larger contact surface and a lower content of micro pores. The analysis of the micrograph showed that the $\mathrm{Cr}_{2} \mathrm{O}_{3}$ coating contains micro pores with an average content of $3.5 \%$. The formed micro pores are black and of irregular shape. 


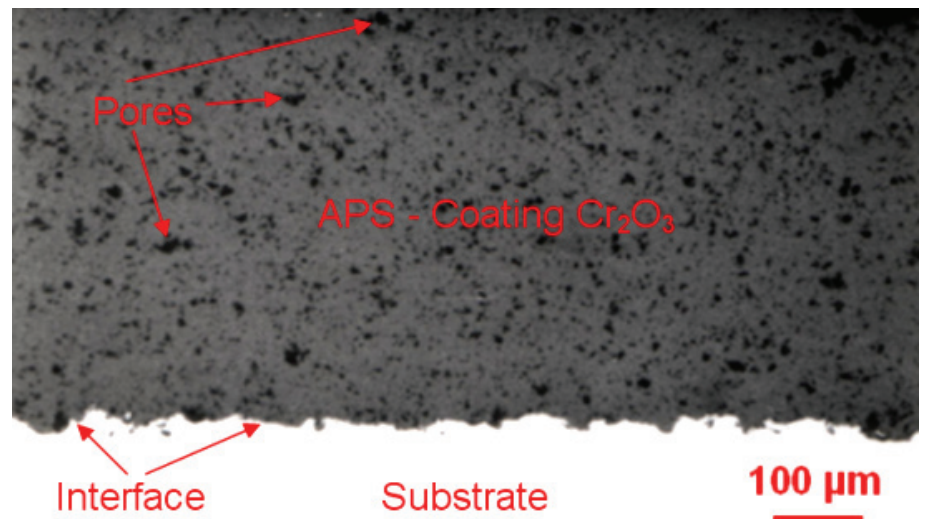

Figure $7-(\mathrm{SEM}) \mathrm{Cr}_{2} \mathrm{O}_{3}$ coating microstructure deposited from a distance of $110 \mathrm{~mm}$ Puc. 7 - (SEM) Микроструктура покрытия $\mathrm{Cr}_{2} \mathrm{O}_{3}$, нанесенного с расстояния 110 мм Слика 7 - (SEM) Микроструктура $\mathrm{Cr}_{2} \mathrm{O}_{3}$ превлаке депоноване са одстојањем $110 \mathrm{~mm}$

Oxide lamellae of the deposited $\mathrm{Cr}_{2} \mathrm{O}_{3}$ coatings are clearly seen in the microstructure. Due to a partial decomposition of the initial dark gray phase of $\alpha-\mathrm{Cr}_{2} \mathrm{O}_{3}$ during plasma powder spraying, other types of oxides such as $\mathrm{Cr}_{3} \mathrm{O}_{4}, \mathrm{CrO}$ and $\mathrm{CrO}_{2}$ (light gray) are present in the microstructure of the coating (Schutz et al, 1991, p.649-669). Micro pores (black) can also be seen in the microstructure of the coating. Figure 8 shows a SEM micrograph of the $\mathrm{Cr}_{2} \mathrm{O}_{3}$ coating surface deposited from a distance of 110 $\mathrm{mm}$ and which had the best mechanical properties and the microstructure. 


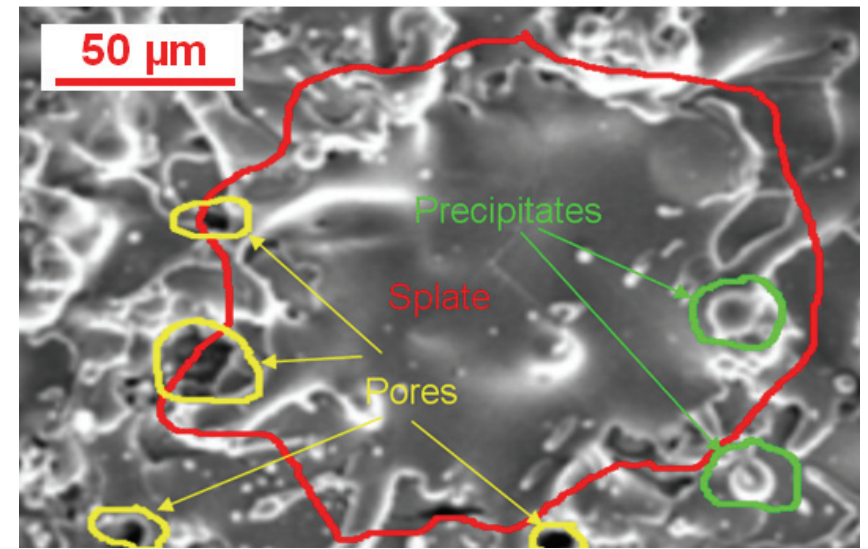

Figure 8-(SEM) Surface morphology of the coatings deposited from a distance of $110 \mathrm{~mm}$ PUc. 8 - (SEM) Морфоология поверхности покрытия, нанесенного с расстояния 110 мм Слика 8-(SEM) Морфологија површине превлаке депоноване са одстојањем $110 \mathrm{~mm}$

The coating surface shows complete melting and spreading of droplets of molten $\mathrm{Cr}_{2} \mathrm{O}_{3}$ particles on the previously deposited layer. The micrograph shows the surface of a molten and evenly distributed $\mathrm{Cr}_{2} \mathrm{O}_{3}$ droplet on the previously deposited layers (circled with a red line). The droplet of a molten powder particle formed a thin disk - splat of an approximately circular shape in a collision with the substrate surface. The deformed droplet, in a collision with the substrate, formed a regular shape, thus creating a good bond with the previously deposited layer. The evenly spilled particle has a lamellar structure in the cross section, as it can be seen in Figure 7.

In the microstructure, there are fine precipitates of approximately spherical size of $10 \mu \mathrm{m}$ formed by breaking off the edges of molten particles in a collision with the substrate. The SEM micrograph shows micro pores (black) up to $10 \mu \mathrm{m}$ circled in yellow.

\section{Conclusion}

The paper analyzes the mechanical properties and the microstructure of the deposited $\mathrm{Cr}_{2} \mathrm{O}_{3}$ layers depending on the distance of the substrate from the plasma gun, on the basis of which the following conclusions are derived.

The mechanical properties and the microstructure of $\mathrm{Cr}_{2} \mathrm{O}_{3}$ coating layers were in accordance with the conditions of the powder deposition. The microhardness values increase with increasing the substrate distance due to a longer stay of powder particles in plasma, which allows complete 
powder melting. The layers deposited from the largest distance have the smallest range and highest microhardness values. These layers have proved to be the thickest. The mean content of micro pores in these layers was the lowest and amounted to $3.5 \%$. Also, the maximum value of the adhesion strength of $48 \mathrm{MPa}$ was found in the layers deposited from the largest distance of the substrate and with the lowest content of micro pores of $3.5 \%$. The mechanical properties of $\mathrm{Cr}_{2} \mathrm{O}_{3}$ layers are in accordance with the microstructures.

In the microstructure of $\mathrm{Cr}_{2} \mathrm{O}_{3}$ layers, besides the initial oxide phase of a-Cr2O3 in dark gray, there are also present $\mathrm{Cr}_{3} \mathrm{O}_{4}, \mathrm{CrO}$ and $\mathrm{CrO}_{2}$ oxides (light gray) due to partial decomposition of the initial oxide. Good mechanical and structural characteristics of $\mathrm{Cr}_{2} \mathrm{O}_{3}$ coating layers deposited on the substrate from a distance of $110 \mathrm{~mm}$ allow its efficient application on steel implants with surfaces exposed to friction without lubrication as well as to corrosion.

\section{References}

-ASM Handbook, 1992, Volume 3, Alloy Phase Diagrams, ASM International, Metals Park.

-ASTM C633-1, 2008. Standard Test Method for Adhesion or Cohesion Strength of Thermal Spray Coatings, Reapproved.

Bag, S. \& Biswas, B.K., 2016. Review on bioactive ceramic coating. International Journal of Pharma and Bio Sciences, 7(2), pp.117-128.

Cetinel, H., Celik, E. \& Kusoglu, M.I., 2008. Tribological behavior of $\mathrm{Cr}_{2} \mathrm{O}_{3}$ coatings as bearing materials. Journal of Materials processing technology, 196(1-3), pp.259-265. Available at: http://dx.doi.org/10.1016/j.jmatprotec.2007.05.048.

Khanna, A. \& Bhat, D.G., 2006. Growth and characterization of chromium oxide thin films prepared by reactive ac magnetron sputtering. Journal of Vacuum Science \& Technology A:Vacuum, Surfaces, and Films, 24, 1870. Available at: http://dx.doi.org/10.1116/1.2244536.

-Material Product Data Sheet, 2012. Metco 106NS Chromium Oxide Thermal Spray Powders, DSMTS-0072.1, Sulzer Metco.

Morks, M.F. \& Akimoto, K., 2008. The Role of Nozzle Diameter on the Microstructure and Abrasionwear Resistance of Plasma Sprayed $\mathrm{Al}_{2} \mathrm{O}_{3} / \mathrm{TiO}_{2}$ Composite Coatings. Journal of Manufacturing Processes, 10(1), pp.1-5. Available at: http://dx.doi.org/10.1016/j.jmapro.2008.10.001.

Mrdak M.R., 2017a. Mechanical properties and the microstructure of the plasma-sprayed $\quad \mathrm{ZrO}_{2} \mathrm{Y}_{2} \mathrm{O}_{3} / \mathrm{ZrO}_{2} \mathrm{Y}_{2} \mathrm{O}_{3} \mathrm{CoNiCrAIY/CoNiCrAIY}$ coating. Vojnotehnički glasnik/Military Technical Courier, 65(1), pp.30-44. Available at: http://dx.doi.org/10.5937/vojtehg65-10586. 
Mrdak, M.R., 2017b. Structure and properties of Ni22Cr10Al1Y coatings deposited by the vacuum plasma spray process. Vojnotehnički glasnik/Military Technical Courier, 65(2), pp. 378-391. Available at: http://dx.doi.org/10.5937/vojtehg65-11904.

Ogwu, A.A., Oje, A.M. \& Kavanagh, J., 2016. Corrosion, ion release and Mott-Schottky probe of chromium oxide coatings in saline solution with potential for orthopaedic implant applications. Materials Research Express, 3(4). Available at: http://dx.doi.org/10.1088/2053-1591/3/4/045401.

Pang, X., Gao, K. \& Volinsky, A.A., 2007. Microstructure and mechanical properties of chromium oxide coatings. Journal Materials Research Society, 22(12), pp.3531- 3537. Available at: http://dx.doi.org/10.1557/JMR.2007.0445.

Schutz, H., Gosmann, T., Stover, D., Buchkremer, H. \& Jager, D., 1991. Manufacture and properties of plasma sprayed $\mathrm{Cr}_{2} \mathrm{O}_{3}$. Materials and Manufacturing Processes, 6(4), pp.649-669. Available at: http://dx.doi.org/10.1080/10426919108934795.

Szafarska, M. \& Iwaszko, J., 2012. Laser remelting teratment of plasmasprayed $\mathrm{Cr}_{2} \mathrm{O}_{3}$ oxide coatings. Archives of metallurgy and materials, 57(1), pp.215-221. Available at: http://dx.doi.org/10.2478/v10172-012-0013-8.

Trifa, F.I., Montavon, G. \& Coddet, C., 2005. On the relationships between the geometric processing parameters of APS and the $\mathrm{Al}_{2} \mathrm{O}_{3}-\mathrm{TiO}_{2}$ deposit shapes. Surface and Coatings Technology, 195(1), p.54-69. Available at: http://dx.doi.org/10.1016/j.surfcoat.2004.07.116.

Wang, M. \& Shaw, L.L., 2007. Effects of Powder Manufacturing Methods on Microstructure and Wear Performance of Plasma Sprayed Alumina-Titania Coatings. Surface and Coating Technology, 202(1), pp.34-44. Available at: https://doi.org/10.1016/j.surfcoat.2007.04.057.

\section{МЕХАНИЧЕСКИЕ ХАРАКТЕРИСТИКИ И МИКРОСТРУКТУРА БИОИНЕРТНЫХ СЛОЕВ ХРОМОКСИДНЫХ ПОКРЫТИЙ, НАНЕСЕННЫХ ВОЗДУШНО-ПЛАЗМЕННЫМ НАПЫЛЕНИЕМ}

\section{Михаило Р. Мрдак}

Центр исследований и развития А.О. «ИМТЕЛ коммуникации», г. Белград, Республика Сербия

ОБЛАСТЬ: химические технологии

ВИД СТАТЬИ: оригинальная научная статья ЯЗЫК СТАТЬИ: английский

\section{Резюме:}

Метод плазменного напыления керамических Cr2O3 покрытий применяется как самостоятельное покрытие, так и в качестве дополнения к биоактивной органической композиционной керамике Ca10(PO4)6(OH)2-Al2O3-ZrO2-Cr2O3 и к иным биоинертным 
керамикам, создавая композиты типа Al2O3-ZrO2-SrO-Cr2O3Y2O3, ZrO2-TiO2-Cr2O3 и TiO2-Cr2O3 с целью улучшения механических характеристик и повышения стойкости к износу и коррозии компонентов протеза сустава. В данной статье представлено каким образом расстояние между пистолетом для плазменного напыления и обрабатываемой поверхностью влияет на механические характеристики и микроструктуру Cr2O3 слоев покрытия, нанесенных при электоромощности $40 \mathrm{kBm}$. Цель нанесения различных слоев заключалась в определении лучших характеристик, которые обеспечат эфрфрективное применение покрытия Cr2O3 для подложек металлических имплантатов, подверженных сухому трению без смазки, а также коррозии живых тканей. Анализ механических характеристик покрытия проведен на основании испытаний микротвердости методом HVO.3 и прочности соединений методом растяжения. Структура слоев испытана методом оптической микроскопии (ОМ), а поверхность испытана методом электронной микрографрии (SEM). На основании полученных характеристик установлено, что эфрфективное применение биоинертных слоев Cr2О3 возможно и в сочетании с другими керамическими покрытиями, предназначенными для изготовления фрункцональных имплантатов.

Ключевые слова: основа, микроструктура, коррозия, керамика.

МЕХАНИЧКА СВОЈСТВА И МИКРОСТРУКТУРЕ БИОИНЕРТНИХ СЛОЈЕВА ХРОМ-ОКСИДНИХ ПРЕВЛАКА ДЕПОНОВАНИХ APS-ПРОЦЕСОМ

Михаило Р. Мрдак

Истраживачки и развојни центар ИМТЕЛ комуникације а.д., Београд,

Република Србија

ОБЛАСТ: хемијске технологије

ВРСТА ЧЛАНКА: оригинални научни чланак

ЈЕЗИК ЧЛАНКА: енгЛесКИ

\section{Сажетак:}

Плазма спреј керамички слојеви $\mathrm{Cr}_{2} \mathrm{O}_{3}$ користе се као засебна превлака или као додатак биореактивној органској композитној керамици $\mathrm{Ca}_{10}\left(\mathrm{PO}_{4}\right)_{6}(\mathrm{OH})_{2}-\mathrm{Al}_{2} \mathrm{O}_{3}-\mathrm{ZrO}_{2}-\mathrm{Cr}_{2} \mathrm{O}_{3}$ и другим биоинертним керамикама, правећи компози типа $\mathrm{Al}_{2} \mathrm{O}_{3}-\mathrm{ZrO}_{2}-\mathrm{SrO}_{-} \mathrm{Cr}_{2} \mathrm{O}_{3}-\mathrm{Y}_{2} \mathrm{O}_{3}$, $\mathrm{ZrO}_{2}-\mathrm{TiO}_{2}-\mathrm{Cr}_{2} \mathrm{O}_{3}$ и $\mathrm{TiO}_{2}-\mathrm{Cr}_{2} \mathrm{O}_{3}$ за повећање механичких карактеристика и отпорности компоненти вештачког зглоба на хабање клизањем и корозију. У раду је анализиран утицај 
одстојања плазма пиштоља од подлоге на механичке карактеристике и микроструктуру $\mathrm{Cr}_{2} \mathrm{O}_{3}$ слојева депонованих са снагом напајања од 40 kW. Циљ рада био је да се депонују слојеви оптималних карактеристика који ће омогућити ефикасну примену $\mathrm{Cr}_{2} \mathrm{O}_{3}$ слојева на подлогама челичних имплантата изложених сувом трењу без подмазивања и корозији живих ткива. Испитивање механичких карактеристика реализовано је испитивањем микротврдоће слојева методом $\mathrm{HV}_{0.3}$ и чврстоће споја методом на затезање. Изглед површине честица праха испитан је методом СЕМ. Микроструктуре слојева анализиране су уз примену оптичког микроскопа (ОМ) и скенинг електронског микроскопа (СЕМ). Резултати испитивања потврдили су могућност ефикасне примене биоинертних слојева $\mathrm{Cr}_{2} \mathrm{O}_{3}$ са другим керамикама намењеним за израду функционалних имплантата.

Кључне речи: подлоге, микроструктура, корозија, керамика.

Paper received on / Дата получения работы / Датум пријема чланка: 13.05.2017. Manuscript corrections submitted on / Дата получения исправленной версии работы / Датум достављања исправки рукописа: 22.06.2017.

Paper accepted for publishing on / Дата окончательного согласования работы / Датум коначног прихватања чланка за објављивање: 24.06.2017.

(C) 2018 The Author. Published by Vojnotehnički glasnik / Military Technical Courier (www.vtg.mod.gov.rs, втг.мо.упр.срб). This article is an open access article distributed under the terms and conditions of the Creative Commons Attribution license (http://creativecommons.org/licenses/by/3.0/rs/).

(c) 2018 Автор. Опубликовано в «Военно-технический вестник / Vojnotehnički glasnik / Military Technical Courier» (www.vtg.mod.gov.rs, втг.мо.упр.срб). Данная статья в открытом доступе и распространяется в соответствии с лицензией «Creative Commons» (http://creativecommons.org/licenses/by/3.0/rs/).

(c) 2018 Аутор. Објавио Војнотехнички гласник / Vojnotehnički glasnik / Military Technical Courier (www.vtg.mod.gov.rs, втг.мо.упр.срб). Ово је чланак отвореног приступа и дистрибуира се у складу са Creative Commons licencom (http://creativecommons.org/licenses/by/3.0/rs/).

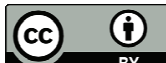

